\title{
Simulation of Thermal Performance and Cost Benefits of Cool Roof Options through Building Engineering System Software
}

\author{
Aftab Ahmed Sahito ${ }^{1}$, Rizwan Ahmed Memon ${ }^{2 a}$, Khanji Harijan² ${ }^{2 b}$, Pervez Hameed Shaikh ${ }^{3}$ \\ RECEIVED ON 04.02.2019, ACCEPTED ON 03.05.2019
}

\begin{abstract}
The cool roofs in buildings is a promising option to deal with summer Urban Heat Island (UHI) effects. In context to that, studies on different cool roof materials are widely available; however, there is a dearth of studies on insulating material benefits and implication for tropical and sub-tropical climate zones. This work investigates thermal performance, energy savings and cost benefits of cool roof materials. For this study, simulation of various cool roof materials such as Marble, Expanded Polyurethane Spray (EPS), Poly Vinyl Chloride (PVC), Spray Polyurethane Foam (SPF) , Extruded Polystyrene Foam (XPS), Thermocol sheet, Asphalt tile, Gypsum tile and Jumbolon-board have been carried out using Energy Plus software package. The results of zone air temperature show that maximum zone air temperature occurs in the month of May. The maximum zone air temperature obtained for conventional roof is $32.1^{\circ} \mathrm{C}$, whereas that for Thermocol sheet, SPF, XPS, Jumbolon-board, EPS, marble, PVC, Asphalt tile and Gypsum tile is 28.8, 28.9, 28.8, 29, 29.1, 31.9, $30.5,30.2$ and $30.7^{\circ} \mathrm{C}$ respectively. Conventional roof surface outside and inside temperature difference is $2.9^{\circ} \mathrm{C}$, whereas, roof surface outside and inside temperature difference for Thermocol sheet, XPS, Jumbolon-board, SPF, EPS, marble, PVC, asphalt tile and gypsum tile is 9.2, 9.3, 8.7, 7.5, 8.1, 3, 3.1, 3.3 and $2.2^{\circ} \mathrm{C}$, respectively. Notably, XPS, Thermocol sheet, SPF, Jumbolon-board, EPS, Marble, PVC, Asphalt tile and Gypsum tile cool roof materials can save around 5.47, 5.38, 5.35, 5.15, 4.93, 1.09, 2.62, 2.31 and 2.18 MWh annually, respectively for the selected building. The payback period for marble, PVC, gypsum tile and asphalt tile is above 1 year, whereas the effective payback period obtained for XPS, Thermocol sheet, SPF, EPS and Jumbolon-board varies from 3 to 6 months. It is concluded that the cool roof materials may be used effectively to save energy and cost.
\end{abstract}

Keywords: Energy Modeling, Simulation, Cool Roof, Thermal Performance, Parametric Study.

\section{INTRODUCTION}

$\mathrm{T}$ The rapidly growing building energy use has raised concerns globally. The total energy consumption of buildings in residential and commercial sectors has steadily increased and reached as high as $40 \%$ in developed countries. Similar trends are reported in Pakistan where energy demand for building is continuously increasing [9]. The heating and cooling demand of a building depends on many factors such as thermal characteristics of building envelope, occupancy schedule, utilization etc. [1,3]. However, the heat gain through roof is the most significant part of heat transfer through building envelope especially single-story buildings like elementary schools and residential houses. It is proved

${ }^{1}$ Directorate of Postgraduate Studies, Mehran University of Engineering and Technology. Email: aasahito@ gmail.com (Corresponding Author)

${ }^{2}$ Department of Mechanical Engineering, Mehran University of Engineering and Technology, Jamshoro, Sindh, Pakistan.

Email: ${ }^{2 a}$ rizwan.hashmani@faculty.muet.edu.pk, ${ }^{2 b}$ khanji.harijan@ faculty.muet.edu.pk

${ }^{3}$ Department of Electrical Engineering, Mehran University of Engineering and Technology, Jamshoro, Sindh, Pakistan, Email: Pervez.hameed@faculty.muet.edu.pk

This is an open access article published by Mehran University of Engineering and Technology, Jamshoro, under CC BY 4.0 International License. 
that the radiative thermal properties of building roof has a great effect on annual energy consumption of a building. The solar reflectance of roofs' surface affects indoor air temperature, thus, heating and cooling energy demand increases significantly, when little or no insulation is present at roof $[4,5]$. The energy balance at roof surface is determined from incident solar radiation, roof surface reflection and absorption, heat transfer, internal and external thermal index and its structure [7]. In order to reduce heating and cooling demand of building, different reflective materials are used to decrease indoor air temperature. Insulating building roof offers various thermal benefits such as surface cooling, dampen temperature oscillations, increased service life of materials, reduced energy consumption, improved environmental quality etc. [6, $11,12,15,20]$. Various studies have found potential benefits, which may vary depending on the type of material, building and roof design, local climate and insulation efficacy. Moreover, cool roof contributes to reduce urban air temperature $[8,10,11]$. The most promising of all are huge energy and cost savings associated with using cooling roof materials $[2,13,14$, 16-19]. There is a dearth of relevant studies on the benefits and implication of insulating material for tropical and sub-tropical climate zones of Pakistan although there are other studies related with building environment [20-22]. Therefore, this study investigates the thermal benefits and implications of cool roof materials through simulation.

\section{METHODOLOGY}

This study is conducted to find the benefits and implications of using cool roof materials in Hyderabad, Sindh region, which is a tropical city of Pakistan. The simulations are performed in EnergyPlus software for naturally ventilated and air conditioned building to assess thermal performance and cost benefits of various cool roof materials. The cool roof materials considered for this study, are those commonly available in the local market i.e., Marble, EPS, PVC, XPS, Thermocol sheet, Asphalt/ asbestos tile, Gypsum tile and Jumbolon-board. The major output variables are surface outside and inside temperature difference, zone air temperature and cooling energy requirement. The outside and inside roof temperatures are obtained from hourly weather data for Hyderabad. An average of 24 hours surface temperature of roof used to find daily inside and outside roof surface temperature. The hourly cooling energy required to overcome the heat flux and maintain required room air temperature is calculated from EnergyPlus software. Annual cooling energy requirement is determined from the sum of hourly cooling energy requirement over the year. Since the building is a single room, the room air-temperature is considered as the zone air-temperature. The analysis is based on the comparative study of conventional roof and roof insulated with various cool roof materials. The main factors taken into account are; cost of material, total installation cost, cooling energy demand, electricity cost saved, and payback period.

The size of building, in this research work, is the average size of office room at MUET, Jamshoro, Pakistan. The geographical parameters of the city used in energy plus software package for simulation are shown in Table 1.

\begin{tabular}{|c|c|}
\hline \multicolumn{2}{|c|}{ Table 1: Geographical Parameters of Hyderabad, } \\
Pakistan
\end{tabular}

The building is single zone and modeled with the help of EnergyPlus software as shown in Fig.1. It is considered as naturally ventilated as well as airconditioned in order to get thermal and energy performance of various cool roof materials. In fenestration, the door is in the south wall, and is madeup of wood. The detailed spatial and architectural dimensions and the coordinates of building are given in Fig. 1 and Table 2.

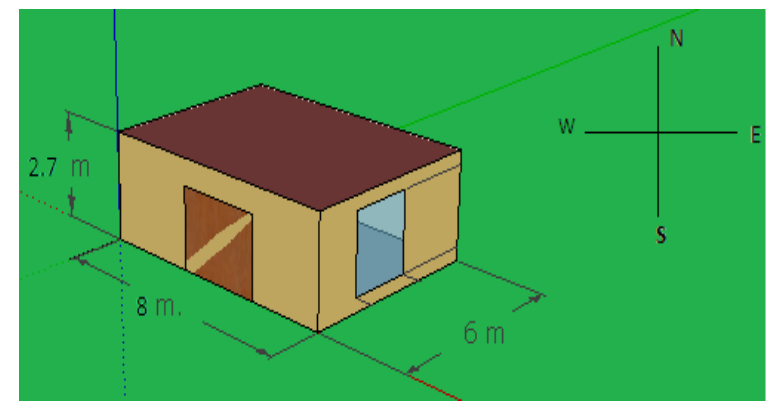

Fig.1: A Single Zone Modelled Building (Length $=8 \mathrm{~m}$, Width $=6 \mathrm{~m}$, Height $=2.7 \mathrm{~m}$, Floor Area $=48 \mathrm{~m}^{2}$ ) 


\section{Simulation of Thermal Performance and Cost Benefits of Cool Roof Options through Building Engineering System Software}

In order to assess thermal performance and cost benefits of various cool roof materials, the basic physical properties of cool roof materials and the heat transfer equations solved for evaluating thermal performance, cost and payback period are given in Tables 3-4, respectively.

\begin{tabular}{|c|c|c|c|c|c|c|}
\hline \multicolumn{7}{|c|}{ Table 2: Boundary Conditions for Selected Building } \\
\hline & Roof & North & East & South & West & Floor \\
\hline Surface Type & Roof & Wall & Wall & Wall & Wall & Floor \\
\hline $\begin{array}{c}\text { Outside Boundary } \\
\text { Condition }\end{array}$ & Outdoors & Outdoors & Outdoors & Outdoors & Outdoors & Indoors \\
\hline Sun Exposure & Yes & Yes & Yes & Yes & Yes & No \\
\hline Wind Exposure & Yes & Yes & Yes & Yes & yes & No \\
\hline View Factor & 0 & 0.5 & 0.5 & 0.5 & 0.5 & 0 \\
\hline
\end{tabular}

\begin{tabular}{|c|c|c|c|c|c|c|c|}
\hline \multicolumn{8}{|c|}{ Table 3: Physical Properties of Cool Roof Materials } \\
\hline Name & Roughness & $\begin{array}{c}\text { Thickness } \\
\text { (m) }\end{array}$ & $\begin{array}{l}\text { Conductivity } \\
(\mathrm{W} / \mathrm{mk})\end{array}$ & $\begin{array}{c}\text { Density } \\
\mathrm{Kg} / \mathrm{m}^{3}\end{array}$ & $\begin{array}{c}\text { Specific } \\
\text { Heat } \\
(\mathrm{J} / \mathrm{Kg}-\mathrm{K})\end{array}$ & $\begin{array}{c}\text { Thermal } \\
\text { Absorptance }\end{array}$ & $\begin{array}{c}\text { Solar } \\
\text { Absorptance }\end{array}$ \\
\hline $\begin{array}{c}* \text { Conventional } \\
\text { Roof }\end{array}$ & $\begin{array}{l}\text { Medium } \\
\text { Rough }\end{array}$ & 0.1 & 1.7 & 2400 & 960 & 0.8 & 0.7 \\
\hline Marble & $\begin{array}{l}\text { Medium } \\
\text { Smooth }\end{array}$ & 0.025 & 2.08 & 2710 & 880 & 0.903 & 0.44 \\
\hline EPS & $\begin{array}{l}\text { Medium } \\
\text { Smooth }\end{array}$ & 0.025 & 0.035 & 30 & 1215 & 0.9 & 0.4 \\
\hline SPF & $\begin{array}{l}\text { Medium } \\
\text { Smooth }\end{array}$ & 0.025 & 0.025 & 35 & 1120 & 0.9 & 0.3 \\
\hline PVC & Smooth & 0.002 & 0.17 & 1350 & 950 & 0.9 & 0.3 \\
\hline ThermocolSheet & $\begin{array}{l}\text { Medium } \\
\text { Smooth }\end{array}$ & 0.05 & 0.035 & 16 & 1215 & 0.9 & 0.4 \\
\hline XPS & $\begin{array}{l}\text { Medium } \\
\text { Rough }\end{array}$ & 0.05 & 0.03 & 32 & 1190 & 0.9 & 0.4 \\
\hline Asphalt Tile & Rough & 0.003 & 0.5 & 1700 & 837 & 0.8 & 0.3 \\
\hline Gypsum Tile & $\begin{array}{l}\text { Medium } \\
\text { Rough }\end{array}$ & 0.0075 & 0.16 & 850 & 1900 & 0.9 & 0.4 \\
\hline Paint & $\begin{array}{l}\text { Medium } \\
\text { Smooth }\end{array}$ & 0.000021 & 1.38 & 1250 & 3060 & 0.8 & 0.2 \\
\hline JumbolonBoard & $\begin{array}{l}\text { Medium } \\
\text { Smooth }\end{array}$ & 0.025 & 0.026 & 38 & 1090 & 0.9 & 0.4 \\
\hline
\end{tabular}

\begin{tabular}{|c|c|}
\hline Parameter & Equation \\
\hline Heat Transfer through Roof & $\mathrm{q}_{\text {roof }}=\varepsilon \sigma\left(\mathrm{T} 4_{\text {roof }}-\mathrm{T} 4_{\text {sky }}\right)\left(\frac{(1+\cos \beta)}{2}\right)+\varepsilon \sigma\left(\mathrm{T} 4_{\text {roof }}-\mathrm{T} 4_{\text {gnd }}\right)\left(\frac{(1-\cos \beta)}{2}\right)$ \\
\hline Zone air Temperature & $\mathrm{qconv}=\sum_{\mathrm{i}=1}^{\mathrm{n} \text { surfaces }}$ hc, i Ai $(\mathrm{Ta}-\mathrm{Ts}, \mathrm{i})$ \\
\hline Thermal Conductivity & $\mathrm{k}=\mathrm{Qdx} / \mathrm{Adt}$ \\
\hline Specific Heat Capacity & $\mathrm{Q}=\mathrm{C}_{\mathrm{p}} \times \mathrm{m} \times \Delta \mathrm{T}$ \\
\hline Over all Heat Transfer Coefficient & $\mathrm{U}=1 / \mathrm{AR}_{\text {total }}$ \\
\hline Payback Period & $\mathrm{PB}_{\mathrm{cr}}=\frac{\mathrm{C}_{\text {Total }}}{\mathrm{CE}_{\text {annum }}} \times \mathrm{N}$ \\
\hline Cost Saving & $\mathrm{C}_{\mathrm{s}}=\mathrm{E}_{\mathrm{s}} \times \mathrm{CE}_{\mathrm{kWh}}$ \\
\hline Net Cooling Energy Requirement & $E_{\text {net }}=E_{\text {Conv }}+E_{R}$ \\
\hline $\begin{array}{c}\text { Installation Cost of Cool Roof } \\
\text { Material }\end{array}$ & $\mathrm{C}_{\mathrm{RM}}=\mathrm{C}_{\mathrm{M}} \times \mathrm{R}_{\mathrm{A}}$ \\
\hline Total Cost & $\mathrm{C}_{\text {Total }}=\mathrm{C}_{\mathrm{RM}}+\mathrm{C}_{\text {labor }}$ \\
\hline Life Span of Cool Roof Material & $\mathrm{N}$ \\
\hline No. of Installations/Year & $\mathrm{N}=1 / \mathrm{n}$ \\
\hline
\end{tabular}




\section{RESULTS AND DISCUSSIONS}

Simulations have been carried on Energyplus software package for naturally ventilated and air-conditioned buildings. This gives results for thermal performance of cool roof materials, roof outside and inside surface temperature, cooling energy requirement, and energy saving potential of each cool roof material.

\subsection{Thermal Performance of Naturally Ventilated Building}

The cool roof materials such as; Marble, EPS, SPF,
PVC, Thermocol sheet, XPS, Gypsum tile, Asphalt tile, Diamond Jumbolon-board have been used to evaluate thermal performance of naturally ventilated building. The building is considered naturally ventilated, as air-conditioning is not used to control indoor thermal environment. The hourly weather data for Hyderabad is used to obtain outside and inside roof surface temperature using EnergyPlus. An average of 24 hours temperature is used to find daily outside and inside roof surface temperature. The comparison of results for cool roof's surface outside and inside temperature, for the selected materials, for the month of July, is shown Figs.2-3, respectively.

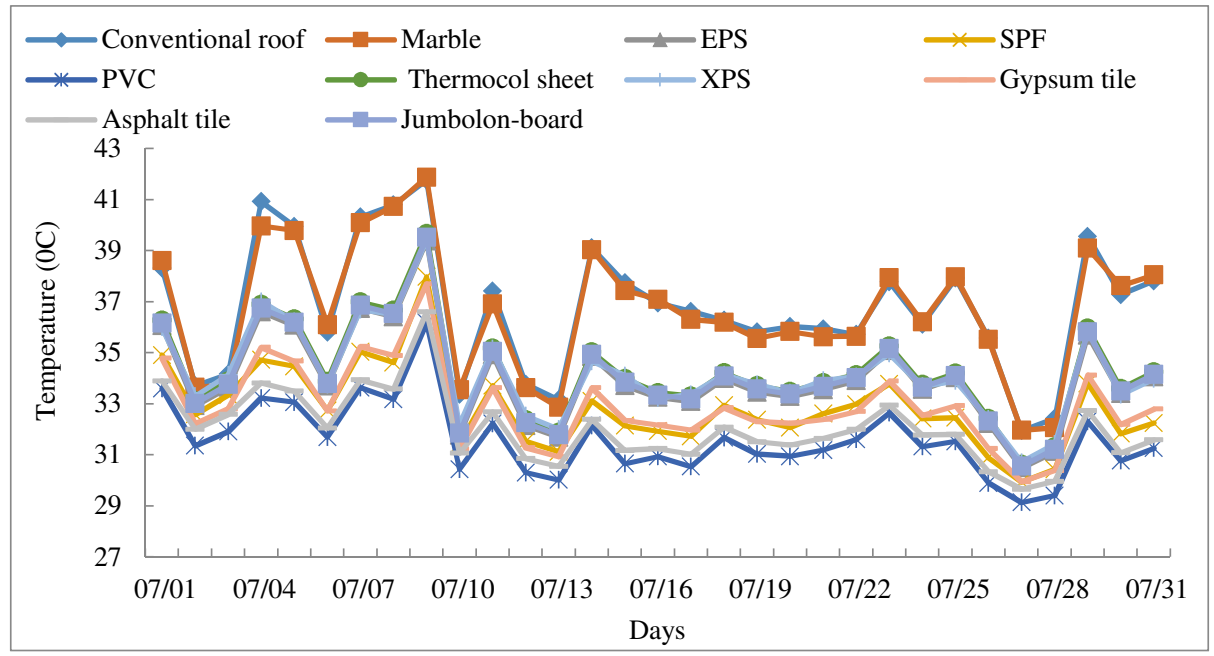

Fig. 2: Daily trends of roof outside surface temperature

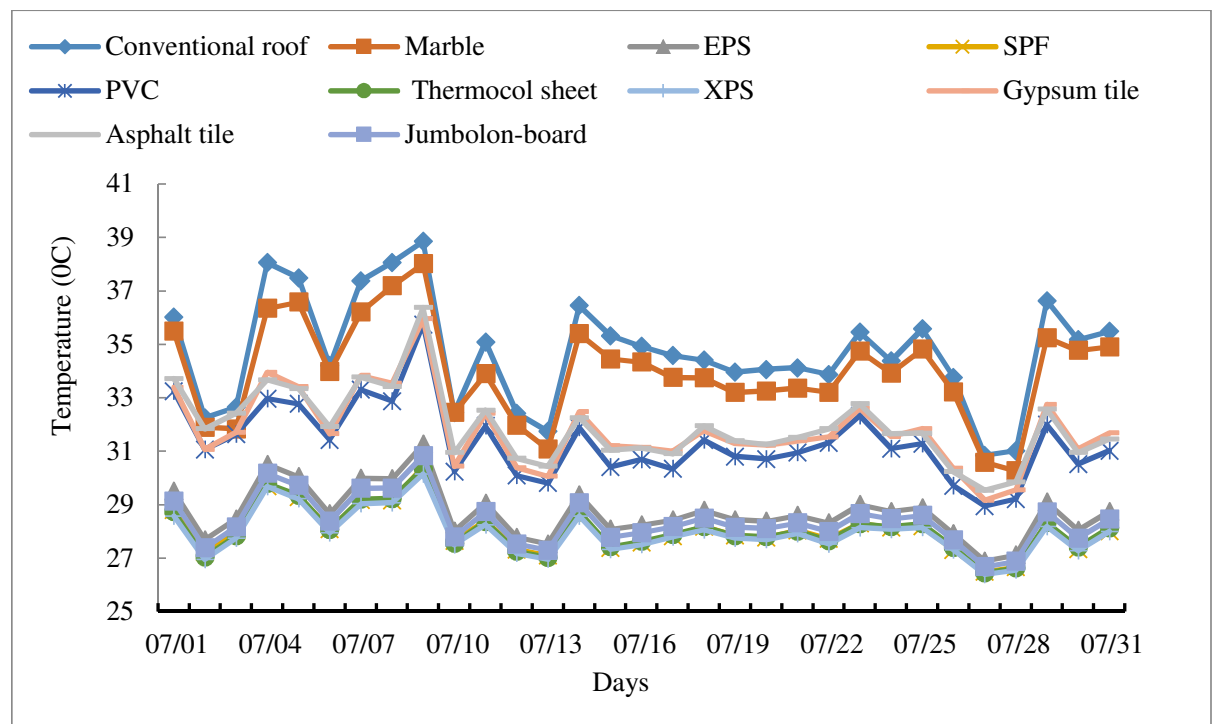

Fig. 3: Daily trends of roof inside surface temperature 
The outside and inside roof surface temperature difference is $2.9^{\circ} \mathrm{C}$ for conventional roof whereas, XPS, Thermocol sheet, jumbolon-board, EPS and SPF are efficient and reduces the roof surface temperature difference by $9.3,9.2,8.7,8.1$ and $7.5^{\circ} \mathrm{C}$, respectively. The comparatively less efficient cool roof materials such as marble, PVC, asphalt tile and gypsum tile reduces temperature by $3,3.1,3.3$ and $2.2^{\circ} \mathrm{C}$ respectively as shown in Table 5 .

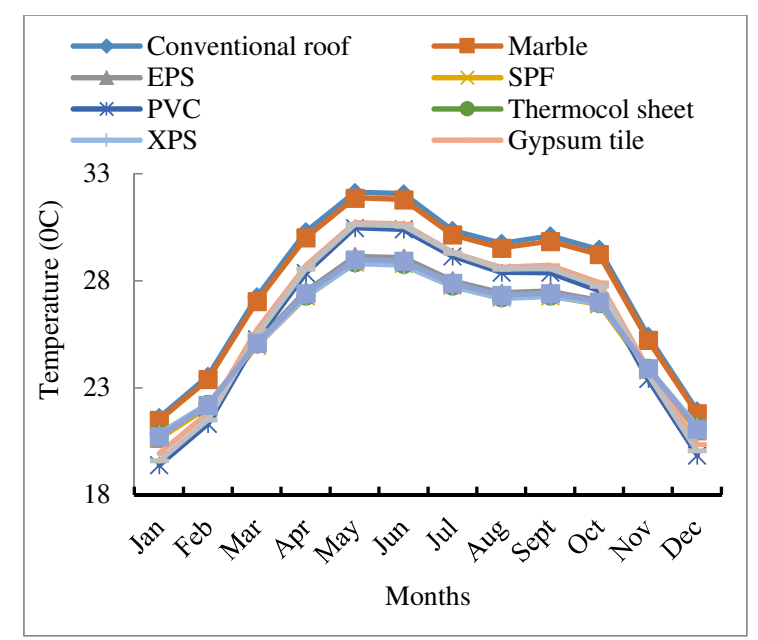

Fig. 4: Monthly Trends of Zone Air Temperature

\begin{tabular}{|c|c|c|c|}
\hline \multicolumn{5}{|c|}{ Table 5: Roof's Outside and Inside Surface Temperature } \\
Difference \\
\hline $\begin{array}{c}\text { Cool Roof } \\
\text { Material }\end{array}$ & $\begin{array}{c}\text { Roof Surface } \\
\text { Outside } \\
\text { Temperature } \\
\left({ }^{\circ} \mathrm{C}\right) \\
\text { (maximum) }\end{array}$ & $\begin{array}{c}\text { Roof Surface } \\
\text { Inside } \\
\text { Temperature } \\
\left({ }^{\circ} \mathrm{C}\right) \\
(\text { maximum })\end{array}$ & $\begin{array}{c}\Delta \mathrm{T} \\
\left({ }^{\circ} \mathrm{C}\right)\end{array}$ \\
\hline $\begin{array}{c}\text { Conventional } \\
\text { Roof }\end{array}$ & 41.8 & 39 & 2.9 \\
\hline Marble & 41.8 & 38.8 & 3 \\
\hline EPS & 39.3 & 31.2 & 8.1 \\
\hline SPF & 37.9 & 30.4 & 7.5 \\
\hline PVC & 38.1 & 35 & 3.1 \\
\hline XPS & 39.4 & 30.1 & 9.3 \\
\hline $\begin{array}{c}\text { Thermocol } \\
\text { Sheet }\end{array}$ & 39.6 & 30.4 & 9.2 \\
\hline Asphalt Tile & 36.6 & 33.3 & 3.3 \\
\hline Gypsum Tile & 37.8 & 35.6 & 2.2 \\
\hline $\begin{array}{c}\text { Jumbolon- } \\
\text { Board }\end{array}$ & 39.5 & 30.9 & 8.7 \\
\hline
\end{tabular}

where $\Delta \mathrm{T}=$ Temperature Difference

Zone air temperature is the indoor temperature of air volume present in a building. A comparison of zone air temperature of different materials with conventional roof and with each other has been made on the basis of thermal performance as shown in Fig. 4. This depicts that maximum zone air temperature is observed with conventional roof in building. While PVC, EPS and Jumbolon-board cool roof materials have lower zone air temperature when applied to building's roof.

The average monthly zone air temperature of conventional roof and cool roof materials like marble, EPS, SPF, PVC, XPS, Thermocol sheet, Gypsum tile, Asphalt tile and Jumbolon-board foam have been simulated and presented in Fig. 4. The month of May found to be the hottest where the maximum zone air temperature reaches to $32.1^{\circ} \mathrm{C}$ with conventional roof whereas maximum zone air temperatures obtained for Thermocol sheet, SPF, XPS and Jumbolon-board is 28.8, 28.9, 28.8 and $29^{\circ} \mathrm{C}$ respectively. Furthermore, comparatively less efficient materials i.e., marble, gypsum tile and EPS observed zone air temperature of $31.9,30.5$ and $30^{\circ} \mathrm{C}$, respectively.

\subsection{Thermal Performance of Air-Conditioned Building}

The thermal performance of conventional roof is compared with various cool roof materials in an airconditioned space. The thermostat set temperature is set at $25^{\circ} \mathrm{C}$ as upper and $17^{\circ} \mathrm{C}$ as lower limit for attaining comfortable indoor thermal environment whereas applied cooling load is in the form of lighting and occupancy. Cooling energy requirement is one of the major output variables to simulate in Energyplus software package. It shows cooling energy required to overcome the heat transfer and maintain the set point temperature.

The energy required to overcome the heat is obtained from simulation as shown in Fig. 5. Results show that highest annual cooling energy is required when the building has a conventional roof i.e., 34566 MJ. Furthermore, total annual cooling energy requirement with other selected cool roof materials is given in Table 6.

The net cooling energy saved is calculated by subtracting the cooling energy required by a building with cooling roof surface from that required by a building with conventional roofing. A comparison of net cooling energy saving with different cool roof materials is shown in MJ and in $\mathrm{kWh}$ in Table 7. 


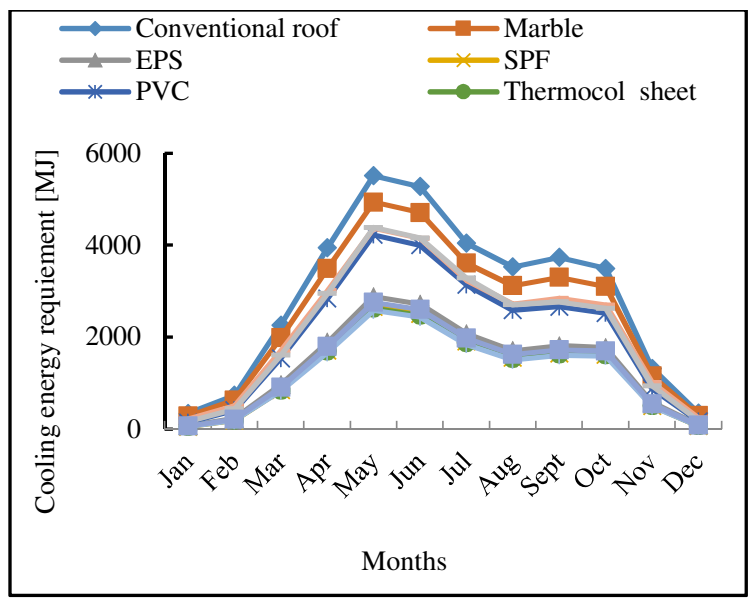

Fig. 5: Monthly Trends of Colling Energy Required

\begin{tabular}{|c|c|}
\hline \multicolumn{2}{|c|}{ Table 6: Total Cooling Energy Required Per Year } \\
\hline Cool Roof Materials & $\begin{array}{c}\text { Total Cooling Energy } \\
\text { Required/Annum } \\
\text { (MJ) }\end{array}$ \\
\hline Conventional & 34566 \\
\hline Marble & 30638 \\
\hline EPS & 16807 \\
\hline SPF & 15279 \\
\hline PVC & 25133 \\
\hline Thermocol Sheet & 15181 \\
\hline XPS & 14874 \\
\hline Gypsum Tile & 26714 \\
\hline Asphalt Tile & 26220 \\
\hline Jumbolon-Board & 16015 \\
\hline
\end{tabular}

\begin{tabular}{|c|c|c|}
\hline \multicolumn{3}{|c|}{ Table 7: Net Cooling Energy Savings per Annum } \\
\hline $\begin{array}{c}\text { Cool Roof } \\
\text { Materials } \\
\text { Cooling } \\
\text { Energy } \\
\text { Saved/Year } \\
(\mathrm{MJ})\end{array}$ & $\begin{array}{c}\text { Annual Energy } \\
\text { Saved/Year } \\
(\mathrm{kWh})\end{array}$ \\
\hline Marble & 3928 & 1091.1 \\
\hline EPS & 17759 & 4933 \\
\hline SPF & 19287 & 5357 \\
\hline PVC & 9433 & 2620 \\
\hline $\begin{array}{c}\text { Thermocol } \\
\text { Sheet }\end{array}$ & 19385 & 5384 \\
\hline XPS & 19692 & 5470 \\
\hline Gypsum Tile & 7852 & 2181 \\
\hline Asphalt Tile & 8346 & 2318 \\
\hline $\begin{array}{c}\text { Jumbolon- } \\
\text { Board }\end{array}$ & 18551 & 5153 \\
\hline
\end{tabular}

The results show that the efficient cool roof materials such as XPS, thermocol sheet, SPF and jumbolon board foam were able to save 5470, 5384, 5357and $5153 \mathrm{kWh}$ of energy per annum, respectively.
Whereas, EPS is competitive and shows better results to save annual cooling energy of about $4933 \mathrm{kWh}$. However, PVC, Asphalt tile and Gypsum tile showed comparatively low cooling energy saving potential.

\subsection{Cost Saving of Cool Roof Materials}

The cost savings can easily be computed as $1 \mathrm{kWh}$ of electricity costs approximately PAKRS. 10/-. Fig. 6 shows percentage cost savings by comparing the electricity cost required to cool a building with conventional roofing and that with cool roof materials. The results show lower cost savings with marble as its installation cost is higher. On the other hand, the optimum cool roof options include XPS, Thermocol sheet, SPF and Jumbolon-board that offers cost savings from $15-16 \%$ annually. EPS, on other hand, seems to be a moderate option with cost savings per annum of up to $14 \%$. The other cool roof materials i.e. gypsum tile, asphalt tile and PVC offers less than $10 \%$ cost saving annually.

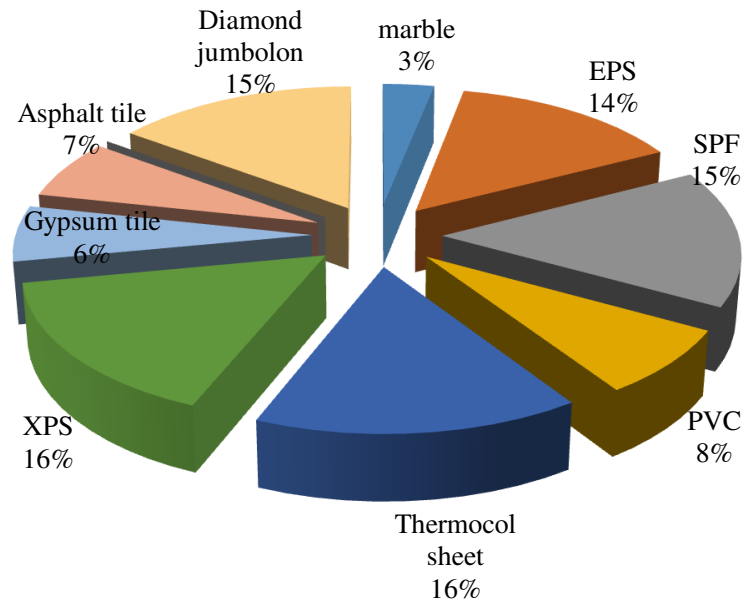

Fig. 6: Cost Saving of Cool Roof Materials

\subsection{Payback Period of Cool Roof Materials}

The cost comparison of various cool roof materials is carried out along with their payback period and the most effective cool roof option has been appraised. Some of the assumptions have been made like 2 labors and one day is required for installation of each option, labor cost per day is PAKRS. 1000/- and cost of electricity is PAKRS. 10/- per unit $\mathrm{kWh}$.

The cost per square meter of each cool roof material has been obtained from local market as shown in Table 
8. The installation cost and payback periods are calculated using relevant equations given in Table 4 . The values of installation cost and annual cooling energy savings are used to obtain payback period.

\begin{tabular}{|c|c|}
\hline \multicolumn{2}{|c|}{ Table 8: Cost of Cool Roof Materials } \\
\hline Cool Roof Material & Cost/sq.m \\
\hline Marble & 646 \\
\hline EPS & 151 \\
\hline SPF & 106 \\
\hline PVC & 1076 \\
\hline ThermocolSheet & 250 \\
\hline XPS & 280 \\
\hline Gypsum Tile & 860 \\
\hline Asphalt Tile & 753 \\
\hline Jumbolon-Board & 387 \\
\hline
\end{tabular}

The type of expected life of material has the biggest impact on payback period although other factors such as exposure to the sun, slope of the roof, type of maintenance etc. do play important role. The average life span of material is used to calculate installations per year of different cool roof materials, as shown in Table 9, and use this data to calculate payback period.

\begin{tabular}{|c|c|c|c|}
\hline \multicolumn{4}{|c|}{ Table 9: Life Span of Cool Roof Materials } \\
\hline $\begin{array}{c}\text { Cool Roof } \\
\text { Materials }\end{array}$ & $\begin{array}{c}\text { Life Span } \\
\text { (years) }\end{array}$ & $\begin{array}{c}\text { Average } \\
\text { Life Span }\end{array}$ & $\begin{array}{c}\text { Installations/Year } \\
(\mathrm{N})\end{array}$ \\
\hline Marble & $20-30$ & 25 & 0.04 \\
\hline EPS & $10-15$ & 12.5 & 0.08 \\
\hline SPF & $15-20$ & 17.5 & 0.06 \\
\hline PVC & $15-30$ & 22.5 & 0.04 \\
\hline $\begin{array}{c}\text { Thermocol } \\
\text { Sheet }\end{array}$ & $5-10$ & 7.5 & 0.13 \\
\hline $\begin{array}{c}\text { Asphalt } \\
\text { Shingle }\end{array}$ & $15-18$ & 16.5 & 0.06 \\
\hline XPS & $10-15$ & 12.5 & 0.08 \\
\hline Gypsum Tile & $5-10$ & 7.5 & 0.13 \\
\hline $\begin{array}{c}\text { Diamond } \\
\text { Jumbolon- } \\
\text { Board }\end{array}$ & $10-15$ & 12.5 & 0.08 \\
\hline
\end{tabular}

The payback period is obtained using the total installation cost, cost saving from electricity and installations per annum as shown in Tables10-11, respectively in relevant equation.

The payback period of each cool roof material is) calculated with two methods. In one method life span of cool roof material has not been considered (Fig. 7(a)) and in the other case life span material is considered (Fig. 7(b)). In the case of without considering life span the cool roof materials, Thermocol sheet and XPS needs payback period of approximately 3 months whereas SPF and Jumbolon board has payback period of about 4 months. The EPS has a bit higher payback period of 6 months. However, all these options seems energy efficient and cost effective. On the other hand, the cool roof materials Asphalt tile, PVC, Gypsum tile and marble seems less efficient with payback period varying from 1.5 to 3 years.

\begin{tabular}{|c|c|}
\hline \multicolumn{2}{|c|}{ Table 10: Cost Saving of Cool Roof Materials } \\
\hline Cool Roof Materials & Cost Saving/Year (Rs) \\
\hline Marble & 10911 \\
\hline EPS & 49330 \\
\hline SPF & 53570 \\
\hline PVC & 26200 \\
\hline Thermocol Sheet & 53840 \\
\hline XPS & 54700 \\
\hline Gypsum Tile & 21810 \\
\hline Asphalt Tile & 23180 \\
\hline Jumbolon-Board & 51530 \\
\hline
\end{tabular}

\begin{tabular}{|c|c|}
\hline \multicolumn{2}{|c|}{ Table 11: Total Installation Cost } \\
\hline Cool Roof Materials & $\begin{array}{c}\text { Total Installation Cost for Roof } \\
\text { Material } \\
\text { (Rs) }\end{array}$ \\
\hline Marble & 33008 \\
\hline EPS & 9248 \\
\hline SPF & 7088 \\
\hline PVC & 53648 \\
\hline Thermocol Sheet & 15440 \\
\hline Asphalt Tile & 38144 \\
\hline XPS & 14000 \\
\hline Gypsum Tile & 43280 \\
\hline Diamond Jumbolon-Board & 20576 \\
\hline
\end{tabular}

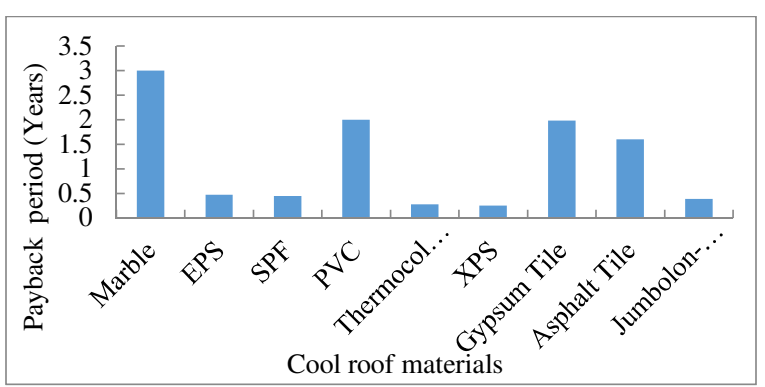

Fig. 7(a): Payback Period of Cool Roof Materials without considering Material Life Span

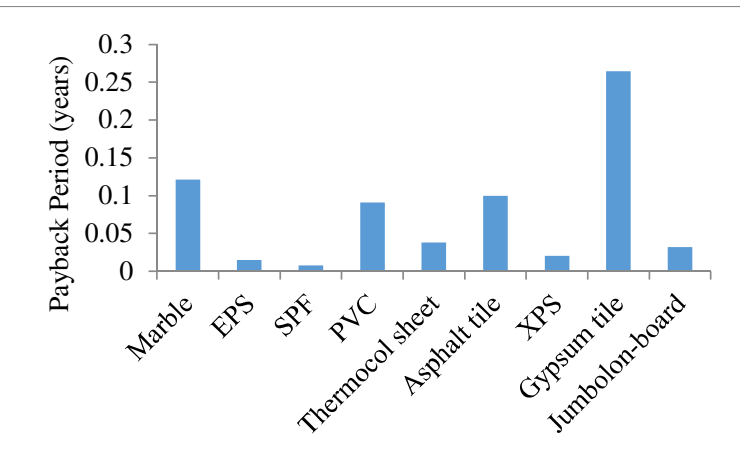

Fig. 7(b): Payback Period of Cool Roof Materials with and without considering Material Life Span 


\section{CONCLUSION}

This work discusses thermal performance, energy saving, cost saving and payback period of using cool roof materials. This work has been carried out by simulating a building in the hot and dry weather of Hyderabad, Pakistan where cooling energy demand is normally very high with high electricity-bills. The comparative analysis of a building with conventional roof and the roof installed with different cool roof materials. The Conventional roof's surface outside and inside temperature difference is $2.9^{\circ} \mathrm{C}$. Thermocol sheet, XPS and Jumbolon-board foam can be considered efficient which reduces surface inside temperature by $9.2,9.3$ and $8.7^{\circ} \mathrm{C}$ respectively. The energy saving potential of EPS, XPS, Thermocol sheet, SPF and Jumbolon-board was 4.9, 5.4, 5.4, 5.3 and 5.1 MWh, respectively. The cost savings for XPS, Thermocol sheet, SPF, Jumbolon-board and EPS are $54,700,53,840,53,570,51,530$ and 49,330 rupees. The effective payback period obtained for XPS, Thermocol sheet, SPF and Jumbolon-board is 3-5 months.

\section{NOMENCLATURE}

\begin{tabular}{|c|c|}
\hline $\mathrm{I}_{\mathrm{t} \theta}$ & Incident solar radiations \\
\hline$\tau \mathrm{E}_{\mathrm{t} \theta}$ & Direct solar radiations \\
\hline$(\mathrm{U} / \mathrm{h} \times \alpha \mathrm{Et} \theta)$ & $\begin{array}{l}\text { Effective heat transfer from absorbed } \\
\text { radiations }\end{array}$ \\
\hline $\mathrm{U}\left(\mathrm{T}_{\mathrm{o}}-\mathrm{T}_{\mathrm{i}}\right)$ & $\begin{array}{l}\text { Effective heat transfer due totemperature } \\
\text { difference }\end{array}$ \\
\hline Fsky $=(1+\cos \beta) / 2$ & View factor of roof to sky \\
\hline $\mathrm{F}_{\mathrm{gnd}}=(1-\cos \beta) / 2$ & View factor of roof to ground \\
\hline $\mathrm{K}$ & Thermal conductivity of a material in W/m-k \\
\hline Q & Heat transfer in Joules \\
\hline A & Area of material in $\mathrm{m}^{2}$ \\
\hline Dx & Thickness of material in meters \\
\hline $\mathrm{Cp}$ & Specific heat capacity of material in $(\mathrm{j} / \mathrm{Kg}-\mathrm{k})$ \\
\hline M & Mass of material in $(\mathrm{kg})$ \\
\hline$\Delta \mathrm{T}$ & Temperature difference $\left({ }^{\mathrm{O}} \mathrm{C}\right)$ \\
\hline $\mathrm{U}$ & Overall heat transfer in $\mathrm{W} / \mathrm{m}^{2} \mathrm{k}$ \\
\hline A & Area in $\mathrm{m}^{2}$ \\
\hline $\mathrm{R}$ & Thermal resistance ${ }^{\circ} \mathrm{C} / \mathrm{W}$ \\
\hline $\mathrm{C}_{\mathrm{RM}}$ & Installation cost of cool roof material \\
\hline $\mathrm{C}_{\mathrm{M}}$ & Cost of material/sq. m \\
\hline $\mathrm{R}_{\mathrm{A}}$ & Area of roof \\
\hline $\mathrm{C}_{\text {Total }}$ & Total cost \\
\hline
\end{tabular}

\section{ACKNOWLEDGEMENT}

The authors would like to thank Mehran University of Engineering and Technology, Jamshoro, Pakistan, to conduct this research.

\section{REFERENCES}

[1] Rafique, M .M., and Rehman .S., "National energy scenario of Pakistan -Current status, future alternatives and institutional infrastructure", Journal of Renewable and Sustainable Energy Reviews, Vol. 69, pp. 156-167, 2017.

[2] Memon, R.A., Chirarttananon, S., and Vangtook, P., "Thermal comfort assessment and application of radiant cooling: A case study", Journal of Building and Environment, Vol. 43, No.7, pp. 1185-1196, 2008.

[3] Salah, K.., Ait-Nouh, F.,Benhamou, B., Limam, K., "Experimental assessment of thermal performance of three passive cooling techniques for roofs in a semi-arid climate", Journal of Energy and Buildings, Vol. 164, pp. 153-164, 2018.

[4] Synnefa, A., Santamouris, M., and Akbari, H., "Estimating the effect of using cool coatings on energy loads and thermal comfort in residential buildings in various climatic conditions", Journal of Energy and Buildings, Vol. 39, pp.1167-1174, 2007.

[5] Kolokotroni, M., Gowreesunker, B.L., and Giridharan, R., "Cool roof technology in London: An experimental and modeling study", Journal of Energy and Buildings, Vol. 67, pp. 658-667, 2013.

[6] Pisello, A. L., and Cotana, F., "The thermal effect of an innovative cool roof on residential buildings in Italy: Results from two years of continuous monitoring", Journal of Energy and Buildings, Vol. 69, pp. 154-164, 2014.

[7] Shaikh. P. H., Nursyarizal B.M.N., Nallagownden. P., Elamvazuthi. I., "Stochastic Optimized Intelligent Controller for Smart Energy Efficient Buildings", Journal of Sustainable Cities and Society, Vol. 13, pp. 41-45, 2014.

[8] Memon, R. A., Tunio, H. A., Lal, K., "Impact of aspect ratio and solar heating on street canyon air temperature" Mehran University Research Journal of Engineering and 
Technology", Vol. 30, No. 1, pp.105-116, 2011.

[9] Androutsopoulos, A.V., Stavrakakis, G. M., and Damasiotis, M., "Cool Roof Impacts on a School-Building Thermal and Energy Performance in Athens, Greece", Journal of Environmental Sciences, Vol. 38, pp. 178186, 2017.

[10] Chadiarakou, S., and Antoniadou, P.," Application of Innovative Composite Cool Thermal Insulating Material for the Energy Upgrade of Buildings", Journal of Environmental Sciences, Vol. 38, pp. 830 835, 2017.

[11] Hernandez, P., Alvarez, G. I., Xaman, J., Guillen, Z. I., Arce, J., and Sima, E., "Thermal performance of reflective materials applied to exterior building components- A review." Journal of Energy and Buildings, Vol. 80, pp. 81-105, 2014.

[12] Zinzi. M., and Carnielo, E., "Impact of urban temperatures on energy performance and thermal comfort in residential buildings. The case of Rome, Italy", Journal of Energy and Buildings, Vol. 157, pp-20-29, 2017.

[13] Memon, R. A., Leung, DYC., "Impacts of environmental factors on urban heating", Journal of Environmental Sciences, Vol. 22, No. 12, pp. 1903-1909, 2010.

[14] Dionysia, D.K., Gerassimos, G., Gobakis, K., Giannarakis, G., Synnefia, A., and Santamouris, M., "Cool roofs and cool pavements application in Achenes, Greece", Journal of Sustainable Cities and Societies, Vol. 37, pp. 466-474, 2018.

[15] Abreu-Harbich, V. L., Chaves. L. A., and Maria Carolina G.O.,"Evaluation of strategies that improve the thermal comfort and energy saving of a classroom of an institutional building in a tropical climate", Journal of Building and Environment, Vol. 135, pp. 257-268, 2018.

[16] Baniassadi, A., Heusinger, J., and Sailor, D. J.,'Building Energy Savings Potential of a Hybrid Roofing System Involving High Albedo, Moisture Retaining Foam Materials", Journal of Energy and Buildings, Vol. 4, pp. 378-388, 2018.
[17]

Dutta, A., and Samanta, A., "Reducing cooling load of buildings in the tropical climate through window glazing: A model to model comparison", Journal of Building Engineering, Vol. 15, pp. 318-327, 2018.

[18] Gracia, A., Navarro, L., Coma, J., Serrano, S., Romani, J., Pérez, G., and Cabeza, F. L., "Experimental set-up for testing active and passive systems for energy savings in buildings", Journal of Renewable and Sustainable Energy Reviews, Vol. 82, pp. 1014-1026, 2018.

[19] Hernandez, P. I., Xaman, E.V., Macias-Melo, K. M., Aguilar-Castro, I., Zavala-Guillen, Z., Lopez, H. and Sima, E., "Experimental thermal evaluation of building roofs with conventional and reflective", Journal of Energy and Buildings, Vol. 158, pp. 569579, 2018.

[20] Harrison, W. W., Piotr, S. M., and Domanski, A., "Selecting HVAC systems to achieve comfortable and cost-effective residential net-zero energy buildings", Journal of Applied Energy, Vol. 212, pp. 577-591, 2018.

[21] Shaheen, N., Arif, S., Arif, K., "Thermal Performance of Typical Residence in Karachi with Different Materials for Construction", Mehran University Research journal of Engineering and Technology", Vol. 35, No. 2, pp.189-198, 2019.

[22] Siddique, S., Arif, S., "Optimum Insulation Thickness for Walls and Roofs for Reducing Peak Cooling Loads in Residential Buildings in Lahore", Mehran University Research Journal of Engineering and Technology", Vol. 35, No. 4, pp.523-532, 2016. 